\title{
Penerapan Model Problem Based Learning dan Inkuiri dalam Pembelajaran Materi Trigonometri di Kelas X SMA Negeri 1 Tabukan Utara
}

\author{
Ayu F. Nikiulu ${ }^{1 *}$, Vivian E. Regar ${ }^{1}$, James U.L. Mangobi ${ }^{1}$
}

1Pendidikan Matematika, Fakultas Matematika dan Ilmu Pengetahuan Alam, Universitas Negeri Manado

e-mail: ayunikiulu@gmail.com

\begin{abstract}
ABSTRAK
Penelitian ini bertujuan untuk melihat perbedaan hasil belajar peserta didik dari penerapan model PBL, Inkuiri, dan model pembelajaran konvensional pada pembelajaran materi Trigonometri. Riset ini diadakan di SMA Negeri 1 Tabukan Utara pada semester ganjil tahun pelajaran 2019/2020. Yang menjadi subjek penelitian adalah siswa kelas X MIA 1 yang berjumlah 26 orang, siswa kelas X MIA 2 yang berjumlah 26 orang, dan siswa kelas X MIA 3 yang berjumlah 24 orang. Metode penelitian yang digunakan dalam riset ini adalah metode eksperimen semu. Dari hasil uji ANOVA diperoleh nilai Fhitung $=$ 6,88, sedangkan nilai $\mathrm{F}_{\text {tabel }}$ dengan taraf signifikan $(\alpha)=0,05$ yaitu sebesar 3,12 . Nilai $\mathrm{F}_{\text {hitung }}>\mathrm{F}_{\text {tabel }}$ yang berarti tolak $\mathrm{H}_{0}$, maka ditarik simpulan ada perbedaan rata-rata hasil belajar yang signifikan pada pembelajaran Trigonometri dengan penerapan model PBL, Inkuiri, dan model pembelajaran konvensional. Selanjutnya, setelah uji lanjutan dengan uji BNT , diperoleh: Rata-rata hasil belajar siswa dari kelas yang diterapkan model PBL tidak berbeda secara nyata dengan kelas yang diterapkan model Inkuiri. Rata-rata hasil belajar siswa dari kelas yang diterapkan model PBL berbeda secara nyata dengan kelas yang diterapkan model pembelajaran konvensional. Rata-rata hasil belajar siswa dari kelas yang diterapkan model Inkuiri berbeda secara nyata dengan kelas yang menerapkan model pembelajaran konvensional.
\end{abstract}

Kata kunci: Hasil Belajar, PBL, Inkuiri

\begin{abstract}
The study aims to see differences in student learning outcomes from the application of PBL, Inquiry, and conventional learning models in learning trigonometric material. This research was conducted at SMA Negeri 1 Tabukan Utara in the odd semester of the 2019/2020 school year. Who became the research subjects were 26 students of class XMIA 1, 26 students of class XMIA 2, and 24 students of class XMIA 3. The research method used in this research is a quasi experimental method. From the ANOVA test results, it was found that the value of $F_{\text {count }}=6,88$, while the value of $F_{\text {table }}$ with a significant level $(\boldsymbol{\alpha})=$ 0,05 , which is 3,12 . The value of $F_{\text {count }}>F_{\text {table }}$ which means reject $H_{0}$, it can be concluded that there is a significant difference in average learning outcomes in Trigonometric learning with the application of PBL, Inquiry, and conventional learning models. Furthermore, after further testing with the LSD test, it was found: The average student learning outcomes from the class that was applied the PBL model were not significantly different from those that applied the Inquiry model. The average student learning outcomes from classes that apply the PBL model are significantly different from those that apply conventional learning models. The average student learning outcomes from classes that apply the Inquiry model are significantly different from those that apply conventional learning models.
\end{abstract}

Keywords: Learning outcomes, Problem Based Learning, Inquiry

\section{PENDAHULUAN}

Kurikulum 2013 dalam penerapannya sesuai untuk diterapkan dalam pembelajaran matematika. Sebab, sasaran dari pembelajaran matematika itu sendiri, yakni siswa diupayakan mampu berpikir secara kritis, logis, serta kreatif dalam menyelesaikan berbagai permasalahan dalam matematika. Lebih lanjut, siswa diharapkan mampu merealisasi konsep dalam pembelajaran matematika tersebut. Akan tetapi, masih terdapat sekolah yang sudah melaksanakan kurikulum 2013 tetapi belum mampu melakukan pembelajaran dengan menerapkan model-model pembelajaran yang bersesuaian dengan kurikulum 2013. Satu diantaranya adalah SMA Negeri 1 Tabukan Utara.

Setelah dilakukan konsultasi dengan guru matematika di SMA Negeri 1 Tabukan Utara, diperoleh bahwa dalam penerapan model maupun metode pembelajaran matematika yang bersesuaian dengan 
kurikulum 2013 masih belum terlaksana secara optimal, dikarenakan guru belum bisa menentukan model atau metode mengajar yang paling tepat untuk diaplikasikan pada tiap materi pelajaran matematika tersebut. Lebih lanjut, siswa kurang mampu dalam memahami pelajaran yang diajarkan dengan desain pembelajaran berbasis sainifik. Penyebabnya ialah penerapan kurikulum 2013 yang masih tergolong baru di sekolah tersebut, sehingga masih membutuhkan waktu untuk penyesuaian, mengingat pula kondisi siswa yang masih terbiasa dengan cara belajar menggunakan metode pembelajaran biasa. Selain itu, kurangnya bimbingan terhadap guru terkait pengimplementasian kurikulum 2013 dalam pembelajaran matematika di kelas, menjadi suatu faktor ketidakoptimalan penerapan metode maupun model pembelajaran saintifik tersebut.

Dampak dari permasalahan ini dalam pembelajaran matematika di sekolah tersebut adalah rendahnya hasil belajar matematika siswa. Setelah diadakan konsultasi lanjutan dengan guru, didapati sejumlah materi yang tergolong sulit dimengerti oleh siswa. Salah satunya yakni materi trigonometri. Guru menjelaskan bahwa setiap ujian akhir semester siswa sering mengalami masalah dalam pengerjaan soal-soal yang berhubungan dengan permasalahan Trigonometri, misalnya perbandingan sudut pada segitiga siku-siku. Hal ini tampak dengan banyaknya siswa yang sering menjawab salah atau kurang tepat pada bagian soal tersebut. Menurut hasil penelitian Nevin (Azni dan Jailani, 2015), yang mengulas tentang kesalahpahaman dan kesalahan siswa pada pembelajaran trigonometri, mengungkapkan faktor utama yang menyebabkan kesalahan siswa ialah dikarenakan metode mengajar yang diterapkan guru, sedangkan kesalahpahaman terjadi dikarenakan pengenalan konsep matematika yang baru kepada siswa. Ketidaktepatan metode pengajaran pada materi trigonometri berakibat pada kekeliruan siswa dalam menangkap konsep dari trigonometri tersebut.

Sesuai dengan hasil wawancara pada beberapa orang siswa kelas XI, yang mana mereka mengungkapkan bahwa mereka masih kurang paham dengan materi trigonometri yang telah diajarkan. Dikarenakan kurangnya motivasi serta minat siswa dalam belajar matematika, disebabkan cara mengajar guru yang kurang inovatif, sehingga kurang bisa membangkitkan motivasi serta minat siswa dalam belajar. Kecenderungan guru dalam melaksanakan pembelajaran menggunakan metode pembelajaran biasa yang menyebabkan guru tidak lagi mencari solusi inovatif lainnya dalam implementasi pembelajaran matematika. Guru hanya melaksanakan pembelajaran dengan menerapkan model pembelajaran konvensional, yakni model pembelajaran langsung dimana dalam penerapannya lebih menitikberatkan guru sebagai penyedia informasi bagi siswa. Alhasil, proses pembelajaran di kelas menjadi pasif bagi siswa, sehingga siswa menjadi kurang termotivasi dalam belajar yang dampaknya dalam pencapaian hasil belajar.

Diperlukan solusi yang tepat untuk memecahkan problematika di atas. Salah satunya adalah dengan menentukan model pembelajaran inovatif yang sejalan dengan implementasi kurikulum 2013. Menurut Sani (2015), terdapat sejumlah model atau desain pembelajaran yang dapat diaplikasikan dengan menggabungkan berbagai komponen pendekatan saintifik dalam pembelajaran, diantaranya: pembelajaran berbasis masalah, pembelajaran berbasis proyek, pembelajaran berbasis inkuiri serta pembelajaran berbasis penemuan.

Model pembelajaran inovatif yang cocok dalam mengatasi problematika di atas adalah model PBL dan inkuiri. Berdasarkan beberapa penelitian sebelumnya, pembelajaran berbasis inkuiri dan pembelajaran berbasis masalah menimbulkan efek positif dalam pembelajaran matematika. Seperti penelitian Rusdi, dkk (2013) yang menyatakan bahwa penerapan dari model pembelajaran inkuiri di kelas X2 SMAN 1 Kota Bengkulu berhasil memberi peningkatan hasil belajar serta keaktifan peserta didik dalam pelajaran trigonometri. Dalam penelitian Santosa, dkk (2018) menyatakan bahwa penerapan strategi inkuiri terbimbing pada pembelajaran materi trigonometri berhasil memberi peningkatan terhadap pemahaman konseptual dan kelancaran prosedural siswa. Dalam penelitian Khotimah, dkk (2016) menunjukkan hasil belajar dari siswa yang meningkat dalam pembelajaran trigonometri dengan penerapan strategi inkuiri, dimana hasil observasi pembelajaran memiliki kategori baik serta hasil tes akhir mengalami peningkatan. Dalam penelitian Junaidi dan Lutfianto (2018) menyatakan bahwa bila ditinjau dari hasil belajar siswa, model PBL dinyatakan efektif bila diterapkan pada pembelajaran trigonometri, yang diperkuat dengan hasil tes akhir yakni 88,88\% siswa mendapat nilai tidak kurang dari 85\%, ini berarti standard keberhasilan tindakan telah tercapai. Dalam penelitian (Wigati, 2016) menunjukkan hasil belajar dari siswa yang meningkat setelah diterapkan model PBL pada pelajaran trigonometri di kelas X-7 SMAN 15 Semarang. Penelitian-penelitian tersebut, kelimanya 
menyatakan bahwa hasil belajar dari siswa pada materi trigonometri menunjukkan peningkatan setelah menerapkan model PBL dan Inkuiri.

Selain itu, model PBL dan Inkuiri juga memiliki beberapa kelebihan dibandingkan model pembelajaran lain. Pemecahan masalah adalah salah satu keunggulan model PBL dimana dapat menantang anak didik dalam mengasah kemampuannya dan memberikan rasa puas dalam menciptakan pengetahuan baru bagi siswa.. Yang dimaksud kemampuan siswa disini adalah kemampuan penalaran siswa. Sedangkan kelebihan dari model pembelajaran Inkuiri ialah inkuiri merupakan suatu desain pembelajaran yang menitikberatkan perluasan aspek afektif, psikomotor, serta kognitif dengan seimbang dengan begitu pembelajaran dengan desain ini dapat lebih bermakna. Dari kelebihan kedua model pembelajaran ini, keduanya menunjukkan adanya dampak yang positif bagi siswa, yakni memberikan motivasi untuk siswa sehingga senantiasa mengembangkan kemampuannya, dan perluasan aspek afektif, psikomotor, serta kognitif siswa.

\section{METODE}

Riset tentang penerapan model Problem Based Learning dan Inkuiri pada pembelajaran materi trigonometri di kelas X Sekolah Menengah Atas Negeri 1 Tabukan Utara telah diadakan pada semester ganjil tahun ajaran 2019/2020 pada tanggal 28 Agustus sampai 9 September 2019. Jenis penelitian yang dipakai adalah quasy eksperiment, dengan memberikan perlakuan (treatment) berupa model PBL, model pembelajaran inkuiri, dan model pembelajaran langsung kepada 3 kelas dan kemudian dilakukan perbandingan hasil belajar dari ketiga kelas tersebut. Rancangan penelitian yang dipakai adalah Rancangan Acak Lengkap (RAL).

Gejala yang dilihat yaitu menyelidiki perbedaan rata-rata hasil belajar matematika siswa melalui penerapan model PBL, Inkuiri, dan model pembelajaran konvensional pada pelajaran trigonometri. Yang menjadi subjek penelitian ialah 26 orang siswa kelas X MIA 1 yang mendapat model PBL, 26 orang siswa kelas X MIA 2 yang mendapat model Inkuiri, serta 24 orang siswa kelas X MIA 3 yang mendapat model pembelajaran konvensional. Teknik yang digunakan dalam mengumpulkan data penelitian yaitu melalui pemberian tes akhir ( posttest) kepada ketiga kelas. Teknik analisis data yang digunakan adalah one way ANOVA. Namun sebelum itu, dilakukan pengujian normalitas dan homogenitas data. Pengujian normalitas dilakukan dengan uji Liliefors, dan untuk pengujian homogenitas dilakukan dengan uji Bartlett.

\section{HASIL DAN PEMBAHASAN}

Penelitian tentang penerapan model Problem Based Learning dan Inkuiri pada pembelajaran materi trigonometri di kelas X SMA Negeri 1 Tabukan Utara ini telah dilakukan. Adapun ringkasan analisis hasil tes akhir (posttest) dari ketiga kelas dinyatakan dalam Tabel 1 di bawah ini, dimana kelas X MIA 1 menerapkan model PBL, kelas X MIA 2 menerapkan model Inkuiri, dan kelas X MIA 3 menerapkan model pembelajaran konvensional.

Tabel 1. Gambaran Data Hasil Belajar Trigonometri Peserta Didik

\begin{tabular}{lcccc} 
No. & Statistik & PBL & $\begin{array}{c}\text { Data Hasil Posttest } \\
\text { Inkuiri }\end{array}$ & Konvensional \\
\hline 1. & Skor Maksimum & 100 & 100 & 94 \\
\hline 2. & Skor Minimum & 35 & 30 & 27 \\
\hline 3. & Jumlah Data Hasil Belajar & 2070 & 1910 & 1408 \\
\hline 4. & Rata-rata & 79,62 & 73,47 & 58,67 \\
\hline 5. & Standar Deviasi (S) & 19,39 & 22,55 & 19,05 \\
\hline 6. & Varians $\left(S^{2}\right)$ & 375,85 & 508,34 & 363,01 \\
\hline
\end{tabular}

Sebelum dilakukan uji hipotesis dengan one way ANOVA, dilakukan pengujian Normalitas data dan uji Homogenitas Varians, untuk mengetahui kenormalan dan keragaman data ketiga kelas yang diambil. Pengujian normalitas data dilkakukan dengan uji Liliefors. Hasil yang diperoleh setelah uji normalitas skor posttest pada kelas yang mendapat perlakuan model PBL menunjukkan nilai $L_{\text {hitung }}=0,15<$ 
$L_{\text {tabel }}=0,17$, hasil uji normalitas skor posttest dari kelas yang diberikan perlakuan model Inkuiri menunjukkan nilai $L_{\text {hitung }}=0,12<L_{\text {tabel }}=0,17$, dan hasil uji normalitas skor posttest dari kelas yang diberikan perlakuan model pembelajaran konvensional menunjukkan nilai $L_{\text {hitung }}=0,06<$ $L_{\text {tabel }}=0,18$. Maka dapat ditarik simpulan bahwa data dari ketiga kelas berdistribusi normal.

Selanjutnya, pengujian homogenitas data posttest ketiga kelas dilakukan dengan uji Bartlett. Hasil yang diperoleh setelah pengujian homogenitas skor posttest memberikan nilai $B_{\text {hitung }}=2,30<$ $\chi_{(0,05,2)}^{2}=5,99$. Artinya varians data ketiga kelas homogen.

Karena data dari ketiga kelas berdistribusi normal serta ragamnya yang homogen, maka data telah memenuhi syarat pengujian hipotesis. Pengujian hipotesis data hasil posttest dari ketiga kelas dilakukan dengan menggunakan one way ANOVA. Hasil yang diperoleh setelah uji hipotesis skor posttest menunjukkan nilai $F_{\text {hitung }}=6,88>F_{\text {tabel }}=3,12$. Yang diartikan ada perbedaan rata-rata hasil belajar peserta didik yang signifikan dalam pembelajaran materi trigonometri dengan penerapan model PBL, inkuiri, dan pembelajaran konvensional. Karena hasil pengujian hipotesis menunjukkan adanya perbedaan rata-rata hasil belajar trigonometri dari pengaplikasian ketiga model pembelajaran, maka diadakan pengujian lanjutan untuk mengetahui rata-rata kelas mana yang lebih tinggi secara signifikan. Uji lanjutan ini dilakukan dengan uji Beda Nyata Terkecil (BNT). (Lolombulan, 2017). Hasil uji lanjutan dengan uji BNT menunjukkan hasil sebagai berikut: (1). Nilai $\left|\bar{x}_{1}-\bar{x}_{2}\right|=6,15<B N T_{\alpha}=11,27$, Ini berarti rata-rata hasil belajar peserta didik pada kelas yang diterapkan model PBL tidak berbeda secara nyata dengan kelas yang diterapkan model inkuiri. (2). Nilai $\left|\bar{x}_{1}-\bar{x}_{3}\right|=20,95>B N T_{\alpha}=11,51$, yang berarti rata-rata hasil belajar peserta didik pada kelas yang diterapkan model PBL berbeda secara nyata dengan kelas yang diterapkan model pembelajaran konvensional. (3). Nilai $\left|\bar{x}_{2}-\bar{x}_{3}\right|=14,8>$ $B N T_{\alpha}=11,51$, ini berarti rata-rata dari hasil belajar peserta didik pada kelas yang diterapkan model inkuiri berbeda secara nyata dengan kelas yang mendapat penerapan model pembelajaran konvensional.

Berdasarkan hasil di atas, terlihat rata-rata hasil belajar peserta didik dalam penerapan model PBL dan model inkuiri tidak berbeda secara nyata. Rata-rata hasil belajar peserta didik dari penerapan model PBL dan inkuiri memiliki perbedaan yang nyata dengan rata-rata hasil belajar peserta didik dari model pembelajaran konvensional, yang mana rata-rata hasil belajar peserta didik dari kedua model ini lebih tinggi secara signifikan dari model pembelajaran konvensional.

Model PBL dan inkuiri berhasil memberi pengalaman belajar yang lebih aktif dan menarik motivasi serta minat belajar siswa pada materi trigonometri melalui pendekatan saintifik. Hal ini didukung dengan banyaknya permasalahan nyata di lingkungan sehari-hari siswa yang berhubungan dengan pelajaran trigonometri, sehingga siswa mampu merespon dan memahami pembelajaran trigonometri dengan penerapan model PBL. Proses pembelajaran secara inkuiri juga berhasil menarik minat dan motivasi siswa karena penerapannya yang praktis sehingga siswa lebih mudah dalam memahaminya. Inilah penyebab kedua model pembelajaran ini mendapat rata-rata hasil belajar tertinggi bila dibandingkan dengan model pembelajaran konvensional.

\section{KESIMPULAN}

Penerapan model PBL, inkuiri, dan model pembelajaran konvensional dalam pembelajaran trigonometri di kelas X SMA Negeri 1 Tabukan Utara menunjukkan adanya perbedaan rata-rata hasil belajar yang signifikan. Dimana rata-rata hasil belajar peserta didik dari penerapan model PBL dan model inkuiri tidak berbeda secara nyata. Rata-rata hasil belajar dari penerapan model PBL dan inkuiri memiliki perbedaan yang nyata dengan rata-rata hasil belajar siswa dari model pembelajaran konvensional, yang mana rata-rata hasil belajar dari kedua model ini lebih tinggi secara signifikan dari model pembelajaran konvensional.

\section{DAFTAR PUSTAKA}

Abdullah, S.R. (2015). Pembelajaran Saintifik untuk Implementasi Kurikulum 2013. Jakarta: Bumi Aksara.

Lolombulan, J.H. (2017). Statistika Bagi Peneliti Pendidikan. Yogyakarta: Andi.

Wigati, S. (2016). Meningkatkan Hasil Belajar Matematika Pokok Bahasan Trigonometri Melalui Model Pembelajaran Berbasis Masalah di Kelas X-7 Semester 2 SMA 15 Semarang Tahun 
Pelajaran 2015/2016. Jurnal Karya Pendidikan Matematika, 3(2). Diambil dari https://jurnal.unimus.ac.id/index.php/JPMat/article/download/2171.

Rusdi, Maulidiya, D., Susanto, E. (2013). Pembelajaran Inkuiri pada Materi Trigonometri untuk Meningkatkan Hasil Belajar dan Aktivitas Siswa Kelas X2 SMAN 1 Kota Bengkulu. Prosiding Seminar SEMIRATA FMIPA, Bekasi Barat. Diambil dari https://jurnal.fmipa.unila.ac.id/semirata/article/download/919.

Junaidi, M.K.P., dan Lutfianto, M. (2018). Pengaruh Problem Based Learning Terhadap Hasil Belajar Siswa pada Materi Trigonometri. Jurnal Elektronik Pembelajaran Matematika, 5(2). Diambil dari https://jurnal.uns.ac.id/jpm/article/download/26038/18265.

Azni, T.N. dan Jailani. (2015). Pengembangan Perangkat Pembelajaran Trigonometri Berbasis Strategi Pembelajaran Inkuiri Melalui Model Pembelajaran Kooperatif Tipe STAD. Jurnal Riset Pendidikan Matematika, 2(2). Diambil dari https://download.garuda.ristekdikti.go.id/article.php.

Khotimah, K., Yuwono, I., dan Rahardjo, S. (2016). Penerapan Pembelajaran Inkuiri untuk Meningkatkan Hasil Belajar Trigonometri pada Siswa Kelas X. Jurnal Pendidikan : Teori, Penelitian, dan Pengembangan, 1(11). Diambil dari https://jurnal.um.ac.id/index.php/jptpp/article/view/8010.

Santosa, A.M., Sisworo, dan Dwiyana. (2018). Pembelajaran Inkuiri Terbimbing untuk Meningkatkan Pemahaman Konseptual Siswa Pada Materi Trigonometri Kelas X SMA. Jurnal Pendidikan : Teori, Penelitian, dan Pengembangan, 3(9). Diambil dari https://journal.um.ac.id/index.php/jptpp/article/view/11539. 